\title{
Witnessing in a Time of Homeland Futurities
}

\author{
Annie Isabel Fukushima
}

\section{Abstract}

Current US rhetorical strategies of imagining a future of the homeland have led to the creation and utilisation of new technologies to contain and manage the border. These responses to the US border and immigration impact anti-trafficking efforts, sustaining a 'homeland futurity'. Homeland futurity draws on and extends discourses of emergency that solidify borders as dangerous and risky. This article traces how homeland futurities emerged in US anti-trafficking efforts. Drawing upon interviews and focus group discussions with service providers and survivors of violence in San Francisco, the article demonstrates how migrant labourers are impacted by a discourse of threat and containment of the border. However, migrant labourers and their allies are innovating to secure a life that mitigates risk through migrant labourers' use of technology. This article illustrates through the example of Contratados.org how technology may facilitate opportunities of future visioning by migrant labourers beyond a homeland futurity, to enact practices that bring to the centre migrants and their experiences through social networking and information sharing on job prospects.

Keywords: homeland futurity, border and immigration, human trafficking, migrant labour, technology

Please cite this article as: A I Fukushima, 'Witnessing in a Time of Homeland Futurities', Anti-Trafficking Review, issue 14, 2020, pp. 67-81, https://doi. org/10.14197/atr.201220145

\section{Introduction}

Although separate issues, migration and human trafficking, and the responses to both, are also interconnected. This article takes on the question of how surveillance and the technologies profiling migrants at borders impact trafficked people. The 1990 s presented seemingly contradictory images in the United States' approach

This is an open-access article distributed under the terms of the Creative Commons Attribution License (CC-BY). Under the CC-BY license, the public is free to share, adapt, and make commercial use of the work. Users must always give proper attribution to the authors and the Anti-Trafficking Review. 
to border control and migration: one gestured towards creating free trade throughout North America under the North American Free Trade Agreement (1994), and the other created a rhetoric of war in which migration from the southern US border was presented as an 'invasion'. Such imaginings of the border supported state arguments for policing and the building of physical structures that collectively ensured a very specific goal: controlling migration. ${ }^{1}$ Immigrants experienced the consequence of such responses in which migration was made more difficult. ${ }^{2}$ In an effort to lobby public support for border surveillance and control, advocates promoting tighter border control policies portrayed the border region as a 'dangerous, out-of-control place, putting residents of the interior at mortal risk' ${ }^{3}$

The control of immigration as a means to construct what and who counts as human in the US has meant billions of dollars are invested into surveillance equipment such as night-vision goggles, seismic sensors, low-light CCTV cameras, high-tech aircraft for nocturnal detection, helicopters, fixed-wing aircrafts, and electronic systems. As stated by Eithne Lubhéid, 'Immigration control is not just a powerful symbol of nationhood and people but also a means to literally construct the nation and the people in particular ways. ${ }^{\prime 4}$ Although physical walls re-emerged in US discourse during the 2016 presidential debates, there was prior investment in a 'virtual wall' through the Secure Border Initiative Network (SBInet), an effort that was discontinued in $2010 .^{5}$ In spite of SBInet being in hiatus, Jeh Johnson, former US Secretary of Homeland Security, framed it as: 'Surveillance technology is the wave of the future.'

The advancements in technologies have resulted in increased policing, where border enforcement agents are spending less time tracking and watching and more time on law enforcement activities. ${ }^{7}$ These technologies of surveillance and security

1 J M Heyman, "Illegality" and the US-Mexico Border: How it is produced and resisted', in C Menjívar and D Kanstroom (eds.), Constructing Immigrant 'Illegality': Critiques, experiences, and responses, Cambridge University Press, 2014, pp. 124-125.

2 A S Camacho, Migrant Imaginaries: Latino cultural politics in the US-Mexico borderlands, New York University Press, New York, 2008, p. 289.

3 Heyman, 2014, p. 115.

4 E Lubhéid, Entry Denied: Controlling sexuality at the border, University of Minnesota Press, Minneapolis, 2002, p. xx.

5 Heyman, 2014, p. 112.

6 J Tanfani, 'Fewer immigrants are being caught crossing US-Mexico border', Los Angeles Times, 25 April 2015, http:/www.latimes.com/nation/immigration/la-naborder-security-20150425-story.html.

7 E Blum, 'Further Reflection', US Customs and Border Protection, retrieved 25 April 2019, https://www.cbp.gov/frontline/frontline-june-az-technology. 
have further constructed and reinforced migrant 'illegality'. ${ }^{8}$ Although some technology and immigration control measures are put in place to prevent human trafficking, research shows that restrictive immigration practices actually create the conditions that make migrants vulnerable to being trafficked, ${ }^{9}$ especially when relying on smuggling networks, or refraining from reporting crimes like human trafficking due to their irregular status or fear of deportation. ${ }^{10}$

State anxieties about national security, migration and human trafficking have authorised enhanced surveillance practices that utilise ubiquitous technologies ${ }^{11}$ _ not unlike in the "War on Terror'12 — wiretaps, Global Positioning Systems (GPS) tracking devices, state issued identification (i.e., the US REAL ID Act of 2005 created new federal standards for identification that also led to tighter policies making it more difficult for asylum seekers), and monitoring records such as travel, telephone, money and financial transactions. ${ }^{13}$ These practices reproduce state-based monitoring through systems of evidence gathering, carceral enforcement, and militarised response. In 2015, the US military's Defense Advanced Research Projects Agency (DARPA) used Memex, in collaboration with seventeen contractors, to monitor the Dark Web. ${ }^{14}$ Memex investigates the Deep Web, also referred to as 'Dark Web' or 'Undernet', ${ }^{15}$ for criminalised activities,

8 C Menjívar and D Kanstroom (eds.), Constructing Immigrant 'Illegality': Critiques, experiences, and responses, Cambridge University Press, 2014, p. 5.

9 W Chapkis, 'Trafficking Migration and Law: Protecting innocents, punishing immigrants', Gender \& Society, vol. 17, no. 6, 2003, pp. 923-937, https://doi.org/10.1177/ 0891243203257477.

10 J M Chacón, 'Tensions and Trade-Offs: Protecting trafficking victims in the era of immigration enforcement', University of Pennsylvania Law Review, vol. 157, no. 6, 2010, pp. 1609-1653.

11 Ibid.; M. Latonero et al., The Rise of Mobile and the Diffusion of Technology-Facilitated Trafficking, University of Southern Carolina, 2012.

12 P Mahdavi, From Trafficking to Terror: Constructing a global social problem, Routledge, New York and London, 2013.

13 Ibid.

14 A I Fukushima, Migrant Crossings: Witnessing human trafficking in the US, Stanford University Press, Stanford, 2019, p. 143.

15 The Dark Web requires special software to access, whereas the Deep Web is any web material that commercial engines are unable to access. R W Gehl, 'Power/Freedom on the Dark Web: A digital ethnography of the Dark Web social network', New Media \& Society, vol. 18, no. 7, 2016, pp. 1219-1235, https://doi.org/10.1177/ 1461444814554900. 
including human trafficking. ${ }^{16}$

The rhetorical strategies and policy implications of policing borders and migration have turned the border into a "zone of indistinction" in which undocumented entrants are rendered exposed and expendable "bare life". ${ }^{17}$ Although the increased technologies and militarisation of the US-Mexico border have been ongoing since the 1990s, migrants continue to cross risking violence, trafficking and even death. ${ }^{18}$ Through advanced technologies and public discourse on the border, it is apparent that US law enforcement, policymakers, social services, and anti-trafficking stakeholders are imagining a 'homeland' where 'border security is the responsibility of Customs and Border Protection. And that national security is everyone's responsibility.' ${ }^{\prime 9}$ These imaginings of the homeland have propagated 'discourses of emergency' which are part of a 'risk management program designed to extract profit from projections of an ever-susceptible border'. ${ }^{20}$

The securitisation of borders through technological advancements and surveillance of migrants in carceral anti-trafficking strategies problematically re-reinforce whose body is encoded as innocent (whiteness as innocent). ${ }^{21}$ Therefore, there is a need to deepen the analysis of technology and human trafficking and how technological responses to immigration are impacting human trafficking survivors and antitrafficking response. As aptly stated by Jennifer Musto and danah boyd, 'A close examination of the trafficking-technology nexus and the sociotechnical interventions initiated on behalf of victims of trafficking in the United States also gestures toward broader tensions that undergird anti-trafficking politics, especially the tenuous lines and perpetually contested boundaries that exist between security

16 J Stone, 'What is Memex? How DARPA's secret search engine trawls the dark web for sex trafficking', International Business Times, 11 February 2015, https://www. ibtimes.com/what-memex-how-darpas-secret-search-engine-trawls-dark-web-sextrafficking-1812958.

17 Walsh cites Giorgio Agamben's notion of bare life. J Walsh, 'Remapping the Border: Geospatial technologies and border activism', Environmental and Planning D: Society and Space, vol. 31, issue 6, 2013, pp. 969-987, p. 973, https://doi.org/10.1068/ d18112.

18 Ibid.

19 R Leonard, 'Connecting the Dots on National Security', Department of Homeland Security, https://www.cbp.gov/frontline/frontline-june-az-technology.

20 A Bahng, Migrant Futures: Decolonizing speculation in financial times, Duke University Press, Durham, 2018, p. 78.

${ }^{21}$ M Thakor, 'Digital Apprehensions: Policing, child pornography, and the algorithmic management of innocence', Catalyst: Feminism, Theory and Technoscience, vol. 4, no. 1, 2018, pp. 1-16, https://doi.org/10.28968/cftt.v4i1.29639. 
and surveillance, protection and punishment, and safety and social control. ${ }^{22}$

In this paper, I build upon the dynamic discussions regarding the technologyhuman trafficking nexus to show, through a multi-part analysis, ${ }^{23}$ how migrant labourers are experiencing this nexus through what Aimee Bahng refers to as a 'homeland futurity'. A homeland futurity encompasses policies, practices, and rhetorical strategies deployed by the state that furthers the belief of an 'alien invasion' to garner support for the militarisation of the border. Consequently, citizens, the state, migrants, and trafficked migrants alike, make decisions about their material present based on the narratives they have constructed about the future. ${ }^{24}$

The consequences of homeland futurities are not abstract. Following the theoretical framing, I offer an analysis of how a homeland futurity has material consequence for trafficked migrant labourers caused by migrant policing. This is accomplished through thematic analysis of qualitative data collected during interviews and focus groups conducted in San Francisco. I show how this global city furthers rhetorical strategies of danger and risk management, which are complicated by the fact that it serves as the epicentre of technological advancements for a homeland futurity that consequently displaces trafficked people and marginalised communities. However, migrant labourers and collaborators are resisting homeland futurities by enacting migrant futures through the use of technology. Following the discussion of San Francisco, I examine Contratados.org as an exemplar for how anti-traffickers are using technology to counter a homeland futurity by facilitating opportunities by and for migrant labourers.

\section{Homeland Futurities}

Anti-trafficking responses often further a homeland futurity. Nation-states implement policies, practices, and rhetorical strategies to further beliefs of danger at the border; these endeavours include the use of technology, which for the trafficking survivor is not without consequence. Within state-sponsored antitrafficking efforts, the border is remade and actions authorised through discursive-yet empirically questionable-heightened state authority. For example, in his 2019 remarks on the control of the southern US border, President Trump offered a particular kind of speculation with regard to the absence of a

22 J L Musto and d boyd, 'The Trafficking-Technology Nexus', Social Politics, vol. 21, no. 3, 2014, pp. 461-483, p. 476, https://doi.org/10.1093/sp/jxu018.

23 N K Denzin and Y S Lincoln, 'Transforming Qualitative Research Methods: Is it a revolution?', Journal of Contemporary Ethnography, vol. 24, issue 3, 1995, pp 349-358, https://doi.org/10.1177/089124195024003006.

24 Bahng, pp. 2-3. 
wall: 'They say walls don't work. Walls work 100 percent... you can't take human traffic - women and girls—you can't take them through ports of entry. You can't have them tied up in the back seat of a car or a truck or a van. They open the door, they look. If they can't see three women with tape on their mouth or three women whose hands are tied. They go through areas where you have no wall. Everybody knows that. ${ }^{25}$

The Trump administration exemplifies how US discourse on human trafficking remakes the border as an imagined terrain where criminality and criminalised activities like human trafficking occur, and which, in turn, legitimises its containment. Trump's remarks painted a picture of the US-Mexico border as defined by invasion and threat that simultaneously erases indigeneity. Therefore, a homeland futurity is an imperial one that furthers a capitalist agenda that contains 'risk' ${ }^{26}$ through militarised responses. In the human trafficking, technology, and immigration nexus, trafficking is used to authorise state-based efforts to further a homeland futurity. Notions of homeland futurities are not limited to the United States. Speculations of risk at a country's borders are delineated in studies and news coverage regarding the risks at borders in regions such as Eastern Europe,${ }^{27}$ or country-specific sites such as Venezuela. ${ }^{28}$ Furthermore, homeland futurities are not limited to the leadership of a country, but necessitate the participation of citizens and non-citizens alike. US anti-trafficking responses have furthered a hegemony of a homeland futurity that has implications for social and legal responses to trafficking in localised contexts. In the next section, I offer a discussion based on interviews with migrant labourers, survivors, service providers, and lawyers that highlights the everyday implications of a homeland futurity on trafficked people in a global city like San Francisco.

25 D Trump, 'Presidential Memorandum for the Secretary of Defense, the Attorney General, and the Secretary of Homeland Security', White House, 4 April 2018, https:// www.whitehouse.gov/presidential-actions/presidential-memorandum-secretary-defense-attorney-general-secretary-homeland-security. Multiple news outlets and reporter interviews with anti-traffickers have challenged reductive imaginings of human trafficking at the border. See: J Krajeski, 'The Hypocrisy of Trump's Anti-Trafficking Argument for a Border Wall', The New Yorker, 5 February 2019, https://www. newyorker.com/news/news-desk/the-hypocrisy-of-trumps-anti-trafficking-argumentfor-a-border-wall.

26 Bahng, p. 12.

27 FRONTEX, 'Eastern European Borders Annual Risk Analysis', FRONTEX, Warsaw, 2015, https://frontex.europa.eu/assets/Publications/Risk_Analysis/EB_ARA_2015. pdf.

28 W Spindler, 'Swollen rivers, mass crowding, add to risks at Venezuela borders', UNHCR, 5 April 2019, https:/www.unhcr.org/news/briefing/2019/4/5ca70ee74/ swollen-rivers-mass-crowding-add-risks-venezuela-borders.html. 


\section{Implications of Homeland Futurities in Anti-Trafficking Response}

In 2018, I led a study on the needs of survivors of violence in San Francisco, California, with a particular focus on human trafficking, intimate partner violence and sexual assault. ${ }^{29}$ Another central story cohered through the interviews with migrant survivors was how homeland futurities had real-life ramifications for them and organisations supporting them. A homeland futurity manifests in localised contexts in the form of anti-migrant policing and structures that protect businesses developing homeland futurity technologies, consequently creating conditions of precarity for migrants, trafficked survivors, and vulnerable communities.

San Francisco is a hub for many technology companies and the workers who support those industries. Yet, gross income inequality impacting migrant labourers and the working poor perseveres. San Francisco is considered one of the most important cities for new technology. ${ }^{30}$ In 2017 , a year before the study commenced, there were 673 human trafficking survivors identified by 22 different agencies in San Francisco. ${ }^{31}$ Migrants in San Francisco are viewed as welcome, comprising 35 per cent of the population, ${ }^{32}$ and the city is recognised as providing sanctuary to undocumented migrants. Nevertheless, technological advancements in the city could not be separated from the tools needed to secure borders, enact surveillance, and control and contain people that, in effect, also displaced the most marginalised-trafficked migrants, the working poor, and the marginally housed.

The raw data for this article was obtained through citywide needs assessment of survivors of violence, including twelve focus groups $(n=93)$ and thirty-nine individual interviews that were audio recorded (53.5 hours) and transcribed verbatim. Participants were recruited from thirty-six organisations, with 40 per cent of the participants identifying as survivors of human trafficking, sexual assault and intimate partner violence. In addition to survivors, participants included professionals who were social service providers, medical providers, attorneys, community-based organisation workers, and government workers. Interviews and focus groups were conducted in Spanish, Mandarin, Cantonese, and English. To examine how homeland futurities emerged, thematic analysis was applied to the

29 A I Fukushima, L Gezinski, and E Boley, Violence Against Women Community Needs Assessment: Report, Department on the Status of Women, San Francisco, 2018.

30 D McNeill, 'Governing a City of Unicorns: Technology capital and the urban politics of San Francisco', Urban Geography, vol. 37, issue 4, 2016, pp 494-513, https:/doi. org/10.1080/02723638.2016.1139868.

31 M Kandel, K Peterson, and R Chambers, 'Human Trafficking in San Francisco: 2017 Data', City and County of San Francisco Department on the Status of Women, 2019.

32 Fukushima, Gezinski, and Boley. 
interviews where survivors spoke explicitly about human trafficking. The qualitative data was coded for themes reflecting migration and homeland futurities, in particular key words representing danger, displacement, immigration climate, and risk management.

Two seemingly contrasting imaginings of migrants were furthered in San Francisco: the perception of migrants as dangerous and the danger migrants face. As an immigration attorney conveyed,

Regardless of all the protections and laws and regulations that make us a sanctuary jurisdiction, people are telling us they're afraid to send their children to school... They're afraid to go to work. They're afraid to seek medical care. They're afraid to go to court. So that has been another overarching theme that's been really difficult.

The discourse of danger described by the migrants and service providers was not only a mechanism of containment at the border, but a means to contain migrants even within the places they call home. As Sara, ${ }^{33}$ a Latina migrant survivor said, 'The only thing I know is that people have been telling me that if somebody knocks on the door, do not open the door. And if somebody is asking questions, not to answer.' She shared with me a pocket card that she kept in her wallet. The pocket card stated the following:

I do not wish to speak with you, answer your questions, or sign or hand you any documents based on my $5^{\text {th }}$ Amendment rights under the United States Constitution.

I do not give you permission to enter my home based on my $4^{\text {th }}$ Amendment rights under the United States Constitution unless you have a warrant to enter, signed by a judge or magistrate with my name on it and that you slide under the door. I do not give you permission to search any of my belongings based on my $5^{\text {th }}$ Amendment rights.

I choose to exercise my constitutional rights.

These Cards are available to citizens and noncitizens alike. ${ }^{34}$

Sara chose not to disclose who gave her the card. Her pocket card illuminated

33 Interview participants' names are replaced with pseudonyms to protect their anonymity.

34 Graphics Communications Conference / International Brotherhood of Teamsters 1324-M. 
how even trafficked migrants live with a particular homeland futurity that comprises of everyday surveillance. However, facing restrictive migration policy and practice was also met with resistance: instead of opening her front door and drawing back the window curtains, migrants like Sara were keeping them closed to minimise neighbourly suspicion. Like Sara, other migrant labourers were holding the pocket cards on their bodies and were shutting themselves in, asserting constitutional rights. The migrant survivors highlighted how they were defined by a homeland futurity where notions of danger were part of their everyday reality. Their descriptions included fears about reporting violence and a lack of trust in the police. For some trafficked migrants, this also meant the enhanced risk of deportation.

Technological innovations furthering a nation state's vision of a homeland futurity are masked by a narrative of wealth. San Francisco's 2018 annual budget was approximately USD 11 billion. However, despite the economic growth from technological innovation, migrant labourers, US citizen-survivors of human trafficking, and the working poor experience material consequences of displacement. In spite of the city's wealth, homelessness grew approximately 30 per cent between 2017 and 2019. ${ }^{35}$ As Q, a queer youth of colour survivor conveyed:

The main problem is mental health and housing, especially in the city. Money is the problem here. That's why so many people are homeless... The root issue is housing and money for a lot of us for being black, brown, trans, queer, disabled. We have all of these intersections and what the city cares about is what? Money, white people, and tech.

What Q's reflection helps to underscore is that technological advancements have occurred alongside migrant and vulnerable communities' heightened displacement and economic precarity. The contradictions are apparent: the technological advancements in San Francisco and Silicon Valley mean that the wealthy companies create the tools needed to secure borders, enact surveillance, and control and contain people. As these aspects of a homeland futurity are furthered, the risks for migrants who seek work and refuge in the United States are also increased, effectively preventing them and other marginalised communities from accessing basic needs such as housing. While there is 'so much money' ${ }^{36}$ in San Francisco, the future of the city is foreclosed to migrants whose legality, means of employment,

35 City and County of San Francisco, 'Homeless Population', 2019, retrieved 19 February 2020, https://sfgov.org/scorecards/safety-net/homeless-population.

36 J C Wong, "We all suffer": Why San Francisco techies hate the city they transformed', The Guardian, 1 July 2019, https:/www.theguardian.com/cities/2019/jul/01/sanfrancisco-big-tech-workers-industry. 
racialisation, and national origins are perceived as a risk in a context that seeks to manage risk. The consequence of a homeland futurity is that migrants remain silent about everyday exploitation ${ }^{37}$ when they are cheated out of their wages, work in dangerous conditions, and are trafficked.

In spite of the city's wealth, narratives of uncertainty and scarcity proliferate for trafficked migrants and the service providers working to support them. As one Asian survivor, Amy, conveyed, 'There is a perception that there's a limited amount of benefits... If there's a limited amount of benefits, then the more people you have to share it amongst, you might get a smaller cut of it.' In this scarcity, migrant survivors are pushed to the margins, living in parts of cities that are underresourced. In living on the margins, the wealth of a city like San Francisco cannot be separated from processes that manage risk.

Risk management in a homeland futurity is fostered through systems of bureaucracy. Mechanisms of bureaucracy create an image of a structure that is organised, orderly, and hierarchically determined. For migrant survivors this means lengthy wait times while navigating legal systems and accessing social services. Migrant labourers, in spite of experiencing trafficking and abuse, are compelled to participate in systems that reduce their own identities into data through participation in a system of biometrics. Take, for example, an Asian migrant survivor, Jennifer, who, in order to apply for immigration relief, was required to have her fingerprints taken as part of the mechanisms of biometrics, an automated recognition system of identity management facilitated by the Department of Homeland Security. Jennifer described her frustration of working with bureaucracies:

I found out the most important is legal aid... And sometimes my lawyer does not reply to me for three to four months... I don't know what happened... I feel so, so helpless. I don't know what to do and I don't know what is my next step. And I need to do the fingerprint [biometrics].

These bureaucracies extend beyond the legal realm into social services. Sofia, a Latina migrant survivor, stated, 'It's hard because you have to repeat everything, you have to tell them over, and then you feel like it's a waste of time... I feel like it should be faster, it should be immediate.' This expectation of immediacy is at odds with immigration bureaucracies which are not mechanisms for access, but for regulation. ${ }^{38}$ The advancements of technology and systems of bureaucracy in

37 D Brennan, Life Interrupted: Trafficking into forced labor in the United States, Duke University Press, Durham, 2014, p. 40.

38 E Codó, Immigration and Bureaucratic Control: Language practices in public administration, Mouton de Gruyter, Berlin, 2008, p. 52. 
immigration control have created a kind of 'homeland futurity' that furthers a different type of violence. The violence of such systems is not simply that migrants wait long hours, but that the bureaucratic system itself is a mechanism of homeland futurity that relegates migrants to a bare life-waiting for extended periods to work legally, to connect with family, and to receive any benefits in a system that for some may take years to come. Without having their basic needs met-housing, food, medicines, and resources - migrants are relegated to subsisting on very little, or surviving through informal work. Migrant survivors regularly described the arduous process of trying to find shelter in San Francisco and living in sub-par, even outright inhumane conditions (i.e., rat-infested or bedbugs-infested homes), as they waited on a long waitlist for housing. The consequence of a risk management society has meant that migrant survivors are unable to afford living in a costly place like San Francisco, and are regularly viewed with suspicion when looking for housing.

The effect of scarcity and fear in current US national policy responses to the border have created an imagined 'perfect victim'39 at the 'dangerous border'. This is facilitated through 'immigration fear' where the 'immigration situation' impacts migrants' access to resources. As described by Sue, an immigration attorney, the US political climate and Trump administration are impacting survivors: 'Five years ago ... our clients [were] not as stressed about public benefits. You know, and they [did] not, I believe, have to wait as long for the pieces to be approved as compared to now because of new federal immigration policies. The [current] political landscape is very different.' Additionally, the strict visa policies mean that migrants are unable to work, earn an income, receive services, and access housing, creating conditions of vulnerability to trafficking.

Through discussing a homeland futurity, organisations, individuals, and antitrafficking responders are also resisting such determinations through speculations of a future that centre a migrant futurity. Such practices that utilised technology to create a counter speculation are illuminated in the organisation called Contratados (Contracted). Contratados is a US-based organisation created in 2013 which exemplifies how anti-traffickers can use technology to counter homeland futurity. In the next section, I analyse a particular venture where migrants use mobile and web technology to enact migrant futures as a means to prevent exploitation and empower survivors.

39 J Srikantiah, 'Perfect Victims and Real Survivors: The iconic victim in domestic human trafficking law', Boston University Law Review, vol. 87, 2007, pp. 157-211. 


\section{Migrant Futurity through Contratados}

In October 2014, Centro de Los Derechos Del Migrante Inc. (Center for the Rights of Migrants-CDM) launched Contratados.org, which allows migrant labourers to anonymously rate employers. ${ }^{40} \mathrm{CDM}$ had found that migrant workers often do not have access to computer-based Internet at home but were accessing the web through mobile phones and Internet cafes. ${ }^{41}$ In an interview with She Innovates, Rachel Micah-Jones, Executive Director of CDM, illuminates a kind of migrant futurity through the platform, when she states: 'Contratados.org, our Yelp++ for migrant workers, is changing the balance of power for migrants. Contratados pools collective worker knowledge and displays it alongside publicly available data culled from various sources. This transparency gives workers unprecedented power to make informed lifechanging decisions. ${ }^{2} 2$ This means that migrants can use the platform to make decisions regarding work opportunities. In 2018, Contratados was selected as one of the Massachusetts Institute of Technology 'Work of the Future Solver' teams, where the platform was described as 'allow[ing] workers to share anonymous information on workplace and recruitment abuses, access rights education materials, and view job opportunities through specific job boards' ${ }^{43}$ Contratados is envisioned as being Yelp, plus Glassdoor and Indeed, with 'information and resources' . ${ }^{44}$

The website is in Spanish and can be translated into English for English-preferred language users. Posts by users are like a bulletin and the organisation does not alter them for legal reasons, or it would be responsible for what goes on the

40 E Ericson Jr., 'A “Yelp” for Migrant Workers: Local nonprofit's tool spreads the word about abusive and deceitful employers and recruiters', City Paper, 10 February 2015, https:/www.citypaper.com/news/mobtownbeat/bcp-a-yelp-for-migrant-workers-localcompanys-tool-spreads-the-word-about-abusive-and-deceitful-employer-20150210story.html.

41 S Melendez, 'Contratados: A Yelp to help migrant workers fight fraud', Fast Company, 9 October 2014, https://www.fastcompany.com/3036812/contratados-is-a-yelp-thatfights-fraud-for-migrant-workers.

42 Interview, Rachel Micah-Jones: Founder and Executive Director, Centro de los Derechos del Migrante, Inc., and Team Lead for Contratados.org, She Innovates, n.d., https://www.sheinnovatesstories.com/rachel-micah-jones-founder-and-executivedirector-centro-de-los-derechos-del-migrante-inc.

43 F Montejo, 'Meet the Solver Teams: Announcing our work of the future innovators', MIT Solve, 23 September 2018, https://solve.mit.edu/articles/meet-the-solver-teamsannouncing-our-work-of-the-future-innovators.

44 R M Micah-Jones, 'Contratados.org', Solve, Massachusetts Institute of Technology, 2017, retrieved 28 April 2019, https://solve.mit.edu/articles/meet-the-solver-teamsannouncing-our-work-of-the-future-innovators. 
website. ${ }^{45}$ Contratados user posts are publicly accessible, where one can find employers (text coded in blue) and employment agencies (text coded in pink). Data from migrant labourers is supplemented by publicly available data. At its creation, the web platform was piloted with 280,000 workers in the US. ${ }^{46}$ By 2018, Contratados had provided resources and information to more than 500,000 migrants, leading to the organisation aiding 6,780 migrant workers with their legal and social needs. ${ }^{47}$

Contratados is unique in that it was co-created by migrant workers and allows them to generate content. As a homeland futurity contains 'threats' through surveillance technologies, organisations like Contratados are utilising technology to resist the relegation of migrant labourers to social death and prevent migrants from entering conditions that may lead to trafficking, by creating information sharing on work and rights across the United States. While this alone is not sufficient to resist a homeland futurity, it is an exemplar of an endeavour in which migrant futurities are possible. Recalling Amy who described scarcity of resources, Contratados provides a contrasting image of a range of jobs across the country.

Through platforms like Contratados, migrants are able to find work, resources and information through user and community generated input. It is this type of technology that makes possible migrant futurity - type of future visioning that shapes present conditions and allows one to imagine a future beyond homeland futurities. The website enables migrants to make decisions to not utilise a company that has a poor review. In one of the 194 jobs posted to the website, one worker describes their experience with an au pair company in San Francisco as follows:

They promised me that I was going to live a total American experience with the family and I am a maid in the house ... I worked for the first three weeks without ... rest ... I worked 16 hours a day. The agency did not help me at all ... The family promised me to use a car and when I arrived they restricted me ... It is a form of modern slavery. Very dangerous. ${ }^{48}$

This au pair company received one star; by contrast, a bakery in San Francisco received an anonymous perfect score of 5 stars. $^{49}$

\footnotetext{
45 Ericson Jr., 2015.

46 Micah-Jones, 2017.

47 Ibid.

48 See: https://contratados.org/es/content/aupaircare-inc.

49 See: https://contratados.org/es/content/capital-cookery-inc.
} 
Contratados allows workers to have information at their fingertips, whereas bureaucracies and state-based agencies may be slow, as Sofia had pointed out. The website includes know your rights information, information on visas, work conditions, sexual harassment, and retaliation. Additionally, the website's resources for workplace and recruitment problems are made readily available and workers can contact CDM for direct legal representation and litigation support.

\section{Conclusion}

I have illuminated in this article why it is essential for critical anti-trafficking scholars and activists to understand how surveillance technologies and nation-state responses to borders and human trafficking cohere to further a 'homeland futurity' Understanding how homeland futurities seek to present a vision and practices about the future of a country through frames of danger, risk management, datafication, and displacement, is central to imagining and articulating new modalities of response to violence including human trafficking. At the same time, it is incorrect to suggest that all technological creations negatively impact trafficked migrants. This article is an invitation to the reader to understand how technological creations can enable responses to human trafficking that do not further a homeland futurity.

It is incumbent on anti-traffickers to take into account the real-life implications of a country's rhetorical and policy decisions regarding immigration. The responses to contain 'threats' and focus on 'danger' have implications for trafficked migrants. As seen in the context of San Francisco, migrant labourers are impacted by responses to further a nation's interest to protect its borders. Homeland futurities are not unique to the United States. Countries around the world are ramping up their immigration policies and practices to regulate and control an imagined future through surveillance, securitisation, and bureaucracy. Italy's former Interior Minister Matteo Salvini enacted policies to fine the owners of migrant rescue ships through a 'security decree' ${ }^{50}$ Mexico enacted raids of migrants to avoid US tariffs; ${ }^{51}$ and the Australian government sought to pass legislation that would expand character test provisions, in effect, setting up policy that would increase the number of people facing deportation. ${ }^{52}$

50 Associated Press, 'UN refugee agency says new Italian law could endanger lives', USNews.com, 6 August 2019, https:/www.usnews.com/news/world/articles/ 2019-08-06/un-refugee-agency-says-new-italian-law-could-endanger-lives.

51 D Agren, 'Mexico tightens southern border security as another day passes with no tariff deal', The Guardian, 6 June 2019, https://www.theguardian.com/world/2019/ jun/06/mexico-migrants-border-guatemala-tariffs.

52 S Martin, "Visa character test change "could mean fivefold rise in deportation", The Guardian, 5 August 2019, https:/www.theguardian.com/australia-news/2019/aug/06/ visa-character-test-change-could-mean-fivefold-rise-in-deportations. 
While not all migrants are trafficked, it is pressing for critical anti-trafficking scholars and activists to pay attention and be responsive to national narratives on migration that further a homeland futurity as it impacts trafficked people, who are the most vulnerable. As delineated in the case example of San Francisco, technologies that create everyday surveillance further a discourse of danger. The technologies of homeland futurities impact all migrants, including those who experience exploitation during or after crossing a national border. Additionally, it is essential for critical human trafficking scholars to contend with homeland futurities and the intersection of migration and trafficking in these precarious times. For if the future is imagined as bleak, dangerous, to be contained, securitised, and controlled, trafficked migrants, regardless of the conditions that led to their abuse, will also be impacted along with their family and community. However, the goal is not to be anti-technology when examining the human traffickingtechnology nexus. Technologies created by and for migrant labourers, and in collaboration with leaders and organisers, make possible a migrant futurity. Contratados is an example of how anti-traffickers can create technologies that counter a homeland futurity by collaborating with migrant survivors.

Acknowledgements: I extend my deep appreciation to the participants of the study in San Francisco, survivors, service providers, Carol Sacco and Dr Emily Murase of the San Francisco Department on the Status of Women, Dr Lindsay Gezinski, my former student Elizabeth Boley, Women of Color Academics at the University of Utah, Dr Hokulani Aikau, Dr Ashley Cordes, Dr Richard Medina, and the Geography Department at the University of Utah. I am also deeply grateful for the feedback received from the guest editors of the special issue of the Anti-Trafficking Review Drs. Jennifer Musto and Mitali Thakor, Editor Borislav Gerasimov, and the two anonymous reviewers of the article.

Dr Annie Isabel Fukushima is an Assistant Professor of Ethnic Studies in the School for Cultural \& Social Transformation, University of Utah. Prior to that, she earned her doctoral degree from the University of California, Berkeley, and was a Mellon Postdoctoral Fellow at Rutgers University. Dr Fukushima is the author of Migrant Crossings: Witnessing human trafficking in the U.S. (Stanford University Press, 2019).Email: a.fukushima@utah.edu 